\title{
THE MANDATE DIVIDE IN POLICY REPRESENTATION. THE SUBSTANTIVE REPRESENTATION OF AGRICULTURAL INTERESTS IN THE HUNGARIAN PARLIAMENT
}

\begin{abstract}
Policy responsiveness is considered an effective tool for representing the aggregated interests of an electoral district. This article asks the question whether or not legislators in a mixedmember electoral system act on the profile of the constituency in their parliamentary work, and if yes, whether the magnitude of their actions is dependent upon mandate type and electoral security. I answer these questions by using data on Hungarian MPs' parliamentary questions, and the agricultural profile of the constituencies between 1998 and 2010. It is found that a larger share of the agricultural population correlates with a greater frequency of agriculture questions. Furthermore, as expected, SMD MPs are more vigilant to the share of the agricultural population than list MPs. Interestingly, MPs remain indifferent to the fierceness of competition: they ask just as any many questions in the case of a safe seat as in the case of stiff competition.
\end{abstract}

\section{Keywords}

Policy representation; Parliamentary questions; Mixed-member electoral system; Agriculture; Hungary 
In accordance with Mayhew's oft-cited starting point, students of the electoral connection consider Members of Parliament (MPs) 'single-minded seekers of re-election’ (Mayhew, 1974). Parliamentarians believe that their actions have an electoral impact, and calibrate their activities in a way that it has the largest (positive) effect on voter choices. In doing so, to some extent, they must take citizen preferences into account, and act in a responsive way. Although they can pursue the ultimate goal of re-election through a number of ways, policy responsiveness has always been one of the most important strategies researchers look at.

In the literature, policy responsiveness usually refers to the governments' willingness to respond to the citizens' policy preferences (Eulau and Karps, 1977). Nevertheless, not only governments, but single representatives may also try to align with the public opinion regarding policy matters to improve the electoral connection. However, as information on citizen preferences is scarce, representatives must rely on other indicators to stay responsive. Census data describing district profile provides particularly useful information. It has been shown on many occasions that MPs act on district characteristics by representing issues particularly important for people living in their constituencies (Cameron, Epstein, and O’Halloran, 1996; Charles S. Bullock and MacManus, 1981; Hero and Tolbert, 1995; Hutchings, McClerking, and Charles, 2004).

However, MPs are not the same in their reactions to the constituents' preferences. On the one hand, electoral rules affect the incentive structures MPs face when seeking re-election. In electoral systems where voters chose directly between candidates, representatives are more responsive to voter demand, while when voters may only express party preferences legislators behave in a more party-centred way (André, Depauw, and Shugart, 2014; Carey and Shugart, 1995). On the other hand, rules of election create different sets of MP tasks and distributions 
of MP resources by distinguishing between different types of mandates. Legislators elected in single-member districts (SMDs) primarily represent constituency interests, while party list MPs may take up alternative tasks, such as parliamentary work.

However, even if legislators hold the same type of mandates, they may not engage in constituency service to the same extent. MPs in safe seats are not likely to take up the costly business of constituency service, because they are not in need for additional vote-seeking, while in districts with stiff competition working for the constituency is an important strategy to improve the candidates' positions (Ashworth and Bueno de Mesquita, 2008; Cain, Ferejohn, and Fiorina, 1987; Dropp and Peskowitz, 2012). Thus, electoral security is expected to affect whether MPs act on the citizens' policy positions or pursue alternative agendas.

To show that MPs indeed act on constituent demand in different ways across the different types of mandates and levels of electoral security, I analyse data from a mixed-member electoral system, where legislators are elected from SMDs and closed party lists. I chose a country in which legislators often alternate between the various types of mandates. In such a case, not only SMD but list MPs are interested in acting upon the district demand in the hopes of an SMD-win at the next elections. Prior research on the mandate divide in mixed-member electoral systems shows that there is indeed a difference between legislators holding different types of mandates in terms of how they act as Members of Parliament (Manow, 2013; Stratmann and Baur, 2002). Nevertheless, a cross-tier contamination effect is observed in cases where candidates may compete in SMDs as well as party lists (Carman and Shephard, 2007). Contamination is one of the reasons why there is sometimes limited evidence for a mandate divide: MPs elected on different tiers are more alike than MPs elected under pure majority and PR rules. 
The questions this study seeks to answer are whether or not legislators in a mixed-member electoral system act on the profile of the constituency in their parliamentary work, and if the magnitude of their reaction is dependent upon mandate type and electoral security. I use Hungarian data to empirically test if the size of the agricultural population in the MPs' districts of nomination affects their questioning practices in parliament during three legislatures (1998-2010). Hungary appears to be a relevant case to investigate the above questions because Hungarian candidates may be nominated in multiple electoral tiers simultaneously. Consequently, a fairly large number of list MPs are electorally connected to the SMDs, which makes them interested in representing constituency issues. This enables the direct comparison of SMD and list MPs.

The results of the multivariate models suggest that a larger share of the agricultural population comes with a greater frequency of agriculture questions. The analysis further supports that even when SMD and list MPs face the same re-election incentives, SMD MPs are more vigilant to the share of the agricultural population than list MPs. Interestingly, MPs remain indifferent to the fierceness of competition: they ask just as any many questions in the case of a safe seat as in the case of stiff competition.

\section{Theoretical framework}

\subsection{Voter demand and district profile}

As many before, this work also starts from the premise of the re-election incentive (Mayhew, 1974): Legislators behave the way they do because their ultimate goal is re-election. 'Policy responsiveness' (Eulau and Karps, 1977), ‘congruence' (Miller and Stokes, 1963) or 
'concurrence' (Verba and Nie, 1987) appears when there is a close association between what constituents want and what governments, parties or legislators do in office. This congruence then serves as the basis for re-election to the next legislature, which makes legislators 'constrained by constituent demand' (Norris, 1997). The literature on the congruence between voter opinion and parliamentary action is vast. Starting with Miller and Stokes (1963), authors have contrasted public opinion on several policy issues and public policy (Brettschneider, 1996; Costello, Thomassen, and Rosema, 2012; Maestas, 2000; Page and Shapiro, 1983; Roberts and Kim, 2011), as well as MP behaviour (Thomassen and Andeweg, 2004).

However, information on voter demand is often scarce. Therefore legislators may use auxiliary information to infer to citizen preferences, such as the social characteristics of their constituencies (Norris, 1997). For instance, in an electoral district with an unemployment problem - even if lacking the information on the actual demand - legislators may conclude that it is expected of them to engage in social policy targeting the reduction of unemployment. Similarly, if a relatively large number of citizens live from agriculture, responsive representatives may actively pursue agricultural policy goals. The literature on the relationship between district characteristics and parliamentary behaviour in the US mostly focuses on the effect of the district's racial composition on roll-call voting (Cameron et al., 1996; Charles S. Bullock and MacManus, 1981; Hero and Tolbert, 1995; Hutchings et al., 2004). Most studies find that the support for redistributive welfare programs in Congress corresponds with the size of the minority population (such as African-Americans and Latinos) in the district.

\subsection{Parliamentary action: questions}


Contrary to the American case, in European democracies, where parties act as unitary actors in parliament, roll-call voting is not the most effective tool through which MPs may express individual policy preferences (Thomassen and Andeweg, 2004). In most European parliaments, legislators have other opportunities to represent policy and constituency interests without breaking party unity. In this article, I focus on one of such parliamentary activities: parliamentary questions. Parliamentary questions are traditionally regarded as mechanisms of government scrutiny: legislators use questions to control government action. However, questions also offer ways of not only asking, but giving information (Russo and Wiberg, 2010), such as advertising personal achievements and raising awareness to constituencyrelated issues (Bailer, 2011; Wiberg and Koura, 1994).

In the European context, the role of parties has to be taken into account when explaining MP action in parliament. Most European legislatures offer both oral and written forms of questioning. The general tendency is that written questions offer legislators more leeway in representing particularistic interests, while oral questions are more rigorously censored by the party leadership. Nevertheless given the MP's re-election incentive, and that the MP's reelection is generally also an interest of the party there is no reason to believe that MP and party preferences differ that much in terms of the legislators' questioning practices. Especially under electoral rules that support personal vote-seeking - such as single member districts -, parties presumably expect MPs to take into account the district demand, which also involves asking questions relevant for the district. Based on the above, the first hypothesis of this article is the following.

H1. The profile of the district positively affects how frequently the relevant policy field appears in the legislator's parliamentary questions. 


\subsection{The mixed-member case}

Legislators, however, are not expected to behave independently of institutional incentives. The general consensus in the literature is that candidate-centred electoral rules encourage constituency work. One of the major aspects in this regard is the electoral formula, which differentiates between single member majority and PR rules. Single member districts create a strong linkage of accountability (Lancaster, 1986), and make SMD MPs more dependent on local support (Curtice and Shively, 2009; Mitchell, 2000). Contrarily, in multi-member constituencies, the geographical overlap among legislators confuses the accountability link (Heitshusen, Young, and Wood, 2005), leaving little room for recognition, and hence, increasing the incentive to free-ride (Cain et al., 1987; Lancaster, 1986).

The study of mixed-member electoral systems is particularly important in uncovering the effect of the electoral formula. A significant difference was registered between MPs holding different mandates in terms of MPs' perceptions of pork barrel allocation (Lancaster and Patterson, 1990), pork barrel politics (Stratmann and Baur, 2002), role perceptions (Klingemann and Wessels, 2001), office allocations (Pekkanen, Nyblade, and Krauss, 2006), attitudes toward party discipline (Montgomery, 1999), legislative (Herron, 2002) and nonlegislative parliamentary behaviour (Manow, 2013) as well as the amount of district work (Bowler and Farrell, 1993).

Sometimes, however, there is only limited evidence to the existence of the mandate divide (Ishiyama, 2000; Lundberg, 2006; Morlang, 1999). Cross-tier contamination makes MPs elected from different tiers more alike than MPs elected under pure majority and PR rules. 
The degree to which contamination affects the MPs' behaviour depends primarily on the practice of dual listing and the powers of the party centre in candidate nomination. With regard to the former, list MPs who were defeated on the SMD tier may still act as 'shadows' of SMD MPs and carry out constituency service (Carman and Shephard, 2007). It has been shown, that MPs in Hungary use constituency questions strategically to stabilize their electoral base: SMD MPs and MPs who are running in SMDs ask significantly more locally oriented questions than legislators not involved in the district-level electoral competition (Chiru, 2015; Papp, 2016). However, when the re-selection of the individual MPs heavily depends on the parties' support, SMD MPs show behavioural and attitudinal patterns similar to that of list members (Bawn and Thies, 2003; Herron, 2002; Thames, 2005).

This study is a strong test of the existence of the mandate divide. If there is a difference between the behaviour of SMD and list MPs in a country where contamination is especially strong (i.e. dual listings and strong party powers in candidate selection), it is very likely that a similar difference is found in cases with less contamination.

H2. The effect of district profile on the number of questions asked in the respective policy area is larger for SMD MPs than list MPs.

\subsection{An indicator of the re-election incentive: electoral security}

Since the district profile may only affect the parliamentary behaviour of MPs who are electorally connected to the districts, this study only considers MPs who were running in SMDs at the previous elections. Therefore, the electoral incentive does not necessarily vary across mandate type in the data: both SMD and list MPs may be interested in competing for 
the SMD seat at the next election, and hence pursue constituency orientation. Thus, a registered difference between mandates may not be attributed to the re-election incentive, but rather to the different circumstances that go with the different mandate types (i.e. different ‘job descriptions', varying resources etc.).

Although the re-election incentive may not be easily shown by comparing the behaviour of SMD and list MPs, taking into account electoral security in the SMDs offers a solution to this problem. When MPs make decisions on allocating their resources to various tasks, the safety of their seats has an effect on how important constituency service should be (Ashworth and Bueno de Mesquita, 2008; Cain et al., 1987; Dropp and Peskowitz, 2012). Electoral security in the district may affect the MPs' strategic behaviour in several ways in a mixed-member electoral system. First, in the case of marginal seats where both the SMD MP and her challenger have a realistic chance to win the district at the next elections, both are encouraged to work harder for the constituency. Second, in districts with large margins, SMD MPs may feel safe, and thus work less for the district. However, although list MPs do not have a real chance to win the district, they may still try to steal votes from the incumbent by demonstrating constituency orientation. Their efforts will be less extensive than those of list MPs who compete in marginal districts though. To sum up, the efforts of both SMD and list MPs are expected to decrease with increasing margin.

H3. The electoral margin in the district negatively affects how much MPs act on the district profile.

\section{A mixed-member case: Hungary}




\subsection{A mixed-member case with dual listing}

To be able to compare SMD and list MPs in terms of how they act on district features, list MPs need also be somehow electorally connected to these districts. Therefore, one needs a country case where candidates may be nominated on multiple tiers at the same time. The consequence of dual listing is that we find MPs in parliament who were nominated in SMDs, but got elected from the party lists. The case of Hungary complies with this condition. Furthermore, dual listing and the parties' strong powers in candidate selection makes crosstier contamination in Hungary especially strong. Thus, if a difference between SMD and list MPs is registered, it is very likely that the mandate divide prevails also in cases with less contamination. Previous studies found evidence for the divide in the Hungarian legislators' role perceptions (Chiru and Enyedi, 2015; Judge and Ilonszki, 1995), roll-call behaviour (Olivella and Tavits, 2014; Thames, 2005), as well as the appearance of local issues in interpellations (Sebők, Molnár, and Kubik, 2017). However, as of yet, no studies have looked at if and how the effect of mandate type manifests in the representation of policy interests.

Moreover, due to dual listing, constituency orientation may be a valid strategy for both SMD and list MPs. While SMD MPs are elected to represent constituency interests, list MPs who were listed in SMDs may act as 'shadows' to SMD MPs (Carman and Shephard, 2007), which helps them stay in competition for the next elections when they may very well be nominated again as SMD candidates.

At the time of investigation (1998-2010) Hungary has a three-tier electoral system. 176 legislators are elected in single member districts, while 210 MPs come from regional and national party lists. Candidates may be listed on all three tiers simultaneously. This practice is 
quite widespread as about 40 per cent of candidates ran on at least two tiers between 1990 and 2010.

\subsection{Policy issue: agriculture}

To select a policy issue along which legislator behaviour is meaningfully analysed, three criteria is to be established. First, the policy field has to be salient. Second, the issue should be unambiguously connected to district characteristics. Third, issue stakeholders should more or less share the same interests, so that district characteristics indeed reflect some kind of aggregate preference. Agriculture as a policy field satisfies all three criteria.

Figure 1 shows the frequency of interpellations regarding the various policy areas tabled between 1990 and 2014 in the Hungarian parliament. The most important issues were identified using the Hungarian data from the Comparative Agendas Project ${ }^{1}$. Interpellations, being strongly controlled by party groups, provide a fair estimation of how salient the issue. Black dots represent the number of agriculture interpellations in each electoral term, while grey dots show interpellations asked in other policy areas. Data indicates that agriculture was a rather important issue during the respective period ${ }^{2}$. Other salient policy fields are health, transportation, law and crime and government operations. However, none of these may be easily connected to certain district characteristics. Furthermore, the interests of people living from agriculture are arguably more homogeneous than those directly concerned with government operations for instance.

\footnotetext{
${ }^{1}$ http://cap.tk.mta.hu/en; https://www.comparativeagendas.net/, Accessed: 31 October 2019.

${ }^{2}$ To read more on the Hungarian parliament's activity in the field of agriculture consult Szilágyi et al. (2017), Olajos and Szilágyi (2015) and Raisz and Szilágyi (2012).
} 
[Figure 1 here]

\section{Data and variables}

The analysis builds on a unique dataset that collects publicly available electoral, sociodemographic and parliamentary activity data on Hungarian MPs nominated in SMDs. Due to dual listing, both SMD and list MPs appear in the data. The dataset covers 904 observations over three parliaments for 517 individual MPs.

\subsection{Dependent variable}

The study tests the effect of district profile on the number of parliamentary questions ${ }^{3}$ asked by Hungarian legislators regarding agriculture. House rules allow for four different types of questions: interpellations, direct, oral, and written questions. Although there are differences between these types in both regulations and the level of party control this study handles questions as a homogeneous mass. It is implicitly assumed that more agricultural questions indicate more interest in the issue. Questions that are addressed to the Minister of Agriculture are regarded agriculture questions. Questions are aggregated to the MP-level, and the number of agriculture questions is assigned to each legislator. The dependent variable has an average

\footnotetext{
${ }^{3}$ The other possibility to measure parliamentary activity is to account for the salience of agriculture within the MPs' questioning record. In this case, MPs with a higher share of agricultural issues within the total number of questions would be regarded as more district oriented. However, this would neglect an important consideration, namely electoral motivations. MPs ask more questions in the hopes of increasing their visibility as legislators who care about agriculture. Visibility may only be increased through the sheer number of agricultural questions, and not the salience of this issue. Let us suppose that we have two MP who both ask 15 agricultural question, and the total number of questions are 20 and 60 respectively. The salience of agriculture would be $0.75(15 / 20)$ and 0.25 (15/60), thus the first MP would be described as more concerned with agriculture. However, both MPs have the same number of opportunities to signal concern for agriculture to the voters, and thus their impact on voters is potentially the same.
} 
value of 3.07 with a standard deviation of 16.2. The distribution of the dependent variable is heavily skewed to the left, which naturally affects modelling strategies (see below). There are a lot of MPs who did not ask agriculture questions $(\mathrm{N}=586)$, and a few who submitted a large amount.

\subsection{Independent variables}

The agricultural character of the SMDs is measured using the census data of the Hungarian Central Statistical Office on the occupational setup of the constituencies. The census applies the International Standard Classification of Occupations (ISCO-88) when classifying residents based on their professional background, such as - most relevantly - 'skilled agricultural and fishery workers' ${ }^{4}$. This category identifies citizens above 15 years of age who make a living from agriculture and fishing. The share of citizens living primarily from agriculture in the district of candidacy is assigned to each MP. To obtain an even distribution for this measure, a log-transformed version is used in the analysis (see Figure 2).

[Figure 2 here]

The second independent variable distinguishes between different mandate types. 58.41 per cent of the legislators with SMD candidacy served as SMD MPs during the respective period, while 41.59 per cent are elected from party lists ${ }^{5}$. Third, in the case of SMD MPs Electoral Margin measures the difference between the vote share of the MP and the runner up, while for

\footnotetext{
${ }^{4}$ http://www.ilo.org/public/english/bureau/stat/isco/isco88/publ3.htm; Accessed: 31 October 2019

${ }^{5}$ This study does not distinguish between regional and national list MPs. In the case of all models of the analysis, robustness checks indicate that while both regional and national list MPs differ from SMD MPs, there is no significant difference between the two list types.
} 
list MPs it shows the difference between the vote share of the MP and the winner of the SMD seat $($ mean $=11 \%$, std. dev. $=9.9 \%)$.

\subsection{Control variables}

For the analysis, I select control variables that have been shown to affect constituency orientation, personal vote-seeking and tendencies of individualization in parliament. The models control for seniority which is measured as the number of terms served in parliament prior to the actual incumbency (Norton and Wood, 1990), elected local positions during the actual electoral term such as mayors and local council members (Shugart, Valdini, and Suominen, 2005), whether or not the MP was born in the constituency (Shugart et al., 2005), whether or not the MP has had an education and occupation related to agriculture, whether or not the MP is a national party leader (Wahlke, Eulau, Buchanan, and Ferguson, 1962), whether or not the MP's party is in government, and party size $e^{6}$

\section{Results}

As the dependent variable is an overdispersed count, I use negative binomial regression with clustered errors across individuals ${ }^{7}$. Model 1 in Table 1 tests the effect of the agricultural population on the number of agricultural questions (H1). Model 2 includes an interaction of the agricultural population and mandate type to sort out differences between SMD and list

\footnotetext{
${ }^{6}$ Party size differentiates between Fidesz and MSZP on the one end, and SZDSZ, KDNP, MDF, FKgP and MIÉP on the other.

${ }^{7}$ Random effects negative binomial models taking into account the panel features of the dataset give similar results. However, the random effects model is not consistent. Thus, models with clustered errors are presented in the article.
} 
MPs regarding the effect of the districts' agricultural character on the number of questions

(H2). Last but not least, Model 3 inserts a three-way interaction to gauge the effect of electoral margin across different types of mandates and varying agricultural population $(\mathrm{H} 3)$. The table displays Incidence Rate Ratios (IRRs).

[Table 1 here]

Results of Model 1 demonstrate a positive effect of the district profile on the number of agriculture questions which confirms $\mathrm{H} 1$ (see also Figure 3). One \% increase in the agricultural population increases the incident rate of asking agriculture questions by a factor of 1.5. Legislators running in an average district (with an agricultural population of $1.4 \%$ ) ask 3.42 agriculture questions on average. A 1 percentage point ${ }^{8}$ increase in the agricultural population $(2.4 \%)$ from the average increases the number of questions to 4.33 .

[Figure 3 here]

Looking at the effect of mandate type in Model 1 we find that SMD MPs ask more than twice as many questions (IRR=2.4) than list MPs. To test if SMD MPs act on the district profile differently than list MPs (H2), Model 2 in Table 1 includes an interaction of district profile and mandate type. Figure 4 helps interpret the significant interaction term. While in districts with no agricultural population, all MPs refrain from asking agriculture questions, in districts with a larger share of people living from agriculture SMD MPs draft more questions. Within the group of SMD MPs, a 1 percentage point increase in the agricultural population from its average value increases the number of agriculture questions from 4.78 to 6.83 . Although list

\footnotetext{
${ }^{8}$ Note that the share of agricultural population is taken into account, and not its natural logarithm. Thus, the unit of increase is percentage point and not percent.
} 
MPs may also be interested in representing district interests in parliament, they do not react to the profile of the district in a similar vein: the increase in the number of agriculture questions is negligible in their case. $\mathrm{H} 2$ is thus confirmed: despite the large probability of cross-tier contamination, there is a mandate divide in the MPs' reactions to the profile of their districts.

[Figure 4 here]

To see if MPs react to electoral incentives such as electoral security a three-way interaction is added to the model (see Model 3 of Table 1). The interaction is not significant: the stiffness of competition does not factor in how MPs react to district profile. Figure 5 visualises two situations: the first panel shows MPs competing in marginal districts, and the second panel presents the case of safe seats. The two figures reveal the same tendencies as Figure 4: SMD MPs act on district demand, while list MPs keep the number of agriculture questions low. Electoral security seems irrelevant. Hence, H3 is rejected.

[Figure 5 here]

In all models, two control variables show significant effects: the party's government status and the MP's education. Starting with the latter, MPs whose studies are connected to agriculture ask 6.26 more agriculture questions ${ }^{9}$. This may be an indication of specialization between MPs. MPs with expertise are more likely to carry out activities related to the respective policy area. With regard to government status, government MPs ask 4.68 questions less on average than opposition MPs ${ }^{10}$. This is the consequence of the role of parliamentary questions. The primary aim of parliamentary questions is government scrutiny. Although

\footnotetext{
${ }^{9}$ The average number of agriculture questions asked by MPs with relevant studies is 8.73 .

${ }^{10}$ The average number of agriculture questions asked by government MPs is 1.29, while this value is 5.97 for opposition MPs.
} 
government MPs increasingly utilize questions to support cabinet members, the overwhelming majority of questions is asked by opposition MPs. Figure 6 shows the predicted number of agriculture questions over the share of the agricultural population and across mandate type and the party's government status. Patterns are similar for both government and opposition MPs and are in correspondence with H2. The difference lies in the number of questions. While government MPs rarely ask more agriculture questions than 5, opposition MPs easily approach 50 in districts with a large share of agricultural population.

[Figure 6 here]

\section{Conclusions}

In this article, I asked whether or not legislators in a mixed-member electoral system act on the profile of the constituency in their parliamentary work, and if yes, whether or not the magnitude of their reaction is dependent upon mandate type and electoral security. I selected Hungary as a case, and tested if Hungarian legislators ask more parliamentary questions regarding agriculture in districts where the size of the agricultural population is also larger. As list MPs may also be electorally interested to pursue the interests of the SMDs due to dual listing, Hungary proved to be an especially suitable case for testing the hypotheses of the paper.

Findings suggest that the agricultural profile of the district matters in explaining the topics of parliamentary questions. Legislators nominated in SMDs with an agricultural population of greater size indeed ask more agriculture questions. This indicates that legislators are able to detect the extent of the demand, and willing to calibrate their parliamentary activities accordingly. However, it remains, of course, unresolved whether they rely on census data to 
obtain information, or the profile of the district is mediated through citizen requests or other sources. Nevertheless, it seems appropriate to say that demand matters: MPs pursuing district seats react to it with greater effort in the respective policy field. This result is especially remarkable as the share of agricultural population ranges between 0 and only about 11 per cent. This means that legislators are sensitive to even quite small differences in district profiles, and the districts do not have to be overwhelmingly agricultural to generate a measurable effect.

Looking at the effect of district profile conditional upon mandate type, the results support the general claim of the literature: even though the characteristics of the Hungarian case invites cross-tier contamination, SMD MPs are more reactive to the size of the agricultural population than list MPs. SMD MPs ask a larger amount of agriculture questions in districts with a larger agricultural population, while a similar pattern is not detectable in the case of list MPs, who keep the number of agriculture questions to a minimum. Because all MPs in the sample share the ambition to run in SMDs, the difference between the mandate types is not necessarily due to the electoral incentive. MPs are very likely to have varying job descriptions and available resources which make SMD MPs more attentive to district needs irrespective of the re-election ambition. To uncover the effect of electoral incentives on the number of agricultural questions, it was also tested if electoral margin alters the effect of mandate type. Interestingly, results demonstrate that the stiffness of competition does not appear to change the logic of the MPs' behaviour: SMD MPs react to district demand, while list MPs ask only a few questions regardless of district profile.

The analysis, of course, has limitations. First, this study does not take up the task of identifying the mechanism through which legislators gather their knowledge about district 
demand. Perhaps, they indeed look at district profile, but more realistically, MPs try to balance between the different interests communicated by companies, lobbyists and prominent local actors. Second, the paper only looks at one policy field. To obtain a broader knowledge on the legislators' responsiveness to citizens' political positions, one needs to look at more policy fields, and apply a more fine-grained measure of citizen preferences. However, in the case of policy fields with heterogeneous interests the legislators' balancing act is a more complex task. Nevertheless, showing that legislators react to the district demand in one policy field, demonstrates that MPs make an effort to calibrate their parliamentary tasks in order to further district interests. 
Table 1 Negative binomial regressions explaining the number of agriculture questions

\begin{tabular}{|c|c|c|c|}
\hline & Model 1 & Model 2 & Model 3 \\
\hline & Testing H1 & Testing H2 & Testing H3 \\
\hline Variable & IRR (SE) & IRR (SE) & IRR (SE) \\
\hline \multicolumn{4}{|l|}{ Independent variables } \\
\hline Agricultural Population (logged) & $1.54(0.14)^{*}$ & $1.23(0.15)$ & $1.14(0.25)$ \\
\hline SMD MP & $2.41(0.60)^{*}$ & $19.54(16.17)^{*}$ & $18.82(24.83)^{*}$ \\
\hline Electoral Margin & $2.41(2.56)$ & $2.28(2.50)$ & $\begin{array}{l}283.46 \\
(1572.959)\end{array}$ \\
\hline Agricultural Population (logged) * SMD MP & & $1.57(0.27)^{*}$ & $1.36(0.39)$ \\
\hline Agricultural Population (logged) * Electoral Margin & & & $1.67(1.81)$ \\
\hline SMD MP * Electoral Margin & & & $1.06(7.67)$ \\
\hline Agricultural Population (logged) $*$ SMD MP $*$ Electoral & & & $4.01(6.28)$ \\
\hline \multicolumn{4}{|l|}{ Margin } \\
\hline \multicolumn{4}{|l|}{ Controls } \\
\hline Seniority & $0.85(0.09)$ & $0.86(0.09)$ & $0.91(0.09)$ \\
\hline Mayor & $0.76(0.38)$ & $0.89(0.46)$ & $0.99(0.56)$ \\
\hline Local council member & $1.03(0.41)$ & $1.01(0.41)$ & $1.04(0.41)$ \\
\hline Local birth & $0.73(0.16)$ & $0.71(0.15)$ & $0.66(0.15)$ \\
\hline Education: agriculture & $3.52(1.39)^{*}$ & $3.73(1.42)^{*}$ & $4.09(1.53)^{*}$ \\
\hline Occupation: agriculture & $1.78(0.72)$ & $1.87(0.74)$ & $1.93(0.68)$ \\
\hline Small party & $1.01(0.23)$ & $0.96(0.22)$ & $0.85(0.19)$ \\
\hline Government MP & $0.21(0.05)^{*}$ & $0.24(0.06)^{*}$ & $0.23(0.05)^{*}$ \\
\hline Party leader & $0.76(0.19)$ & $0.79(0.19)$ & $0.71(0.18)$ \\
\hline Constant & $22.30(13.44)^{*}$ & $7.05(5.07)^{*}$ & $3.56(3.87)$ \\
\hline $\mathrm{N}$ & 870 & 870 & 870 \\
\hline Log-pseudolikelihood & -1322.06 & -1318.46 & -1312.39 \\
\hline Wald Chi2 & $133.92 *$ & $144.76^{*}$ & $169.49 *$ \\
\hline
\end{tabular}

$* \mathrm{p}<0.05$

Entries are incidence rate rations. Standard errors are clustered across individual legislators. 
Figure 1 The frequency of agricultural interpellations between 1990 and 2014

Figure 2 The distribution of the agricultural population

Figure 3 The predicted number of agriculture questions as a function of the size of agricultural population

Figure 4 The predicted number of agriculture questions across different mandate types as a function of the size of agricultural population

Figure 5 The predicted number of agriculture questions across different mandate types as a function of the size of agricultural population and electoral margin

Figure 6 The predicted number of agriculture questions across different mandate types and government status as a function of the size of agricultural population 


\section{References}

André, A., Depauw, S. and Shugart, M. S. (2014) 'The Effect of Electoral Institutions on Legisltive Behaviour', in S. Martin, T. Saalfeld and K. Strøm (eds.), The Oxford Handbook of Legislative Studies. Oxford: Oxford University Press.

Ashworth, S. and Bueno de Mesquita, E. (2008) 'Electoral Selection, Strategic Challenger Entry, and the Incumbency Advantage', The Journal of Politics, 70(4), 1006-25.

Bailer, S. (2011) 'People’s Voice or Information Pool? The Role of, and Reasons for, Parliamentary Questions in the Swiss Parliament', The Journal of Legislative Studies, 17(3), 302-14.

Bawn, K. and Thies, M. F. (2003) 'A Comparative Theory of Electoral Incentives Representing the Unorganized Under PR, Plurality and Mixed-Member Electoral Systems', Journal of Theoretical Politics, 15(1), 5-32.

Bowler, S. and Farrell, Da. M. (1993) 'Legislator Shirking and Voter Monitoring: Impacts of European Parliament Electoral Systems upon Legislator - Voter Relationships', Journal of Common Market Studies, 31(1), 45-70.

Brettschneider, F. (1996) 'Public opinion and parliamentary action: Responsiveness of the German Bundestag in comparative perspective', International Journal of Public Opinion Research, 8(3), 292-311.

Cain, B., Ferejohn, J. and Fiorina, M. P. (1987) The personal vote: constituency service and electoral independence. Harvard University Press.

Cameron, C., Epstein, D. and O’Halloran, S. (1996) 'Do Majority-Minority Districts Maximize Substantive Black Representation in Congress?', American Political Science Review, 90(4), 794-812.

Carey, J. M. and Shugart, M. S. (1995) 'Incentives to Cultivate a Personal Vote: a Rank Ordering of Electoral Formulas', Electoral Studies, 14(4), 417-39. 
Carman, C. and Shephard, M. (2007) 'Electoral Poachers? An Assessment of Shadowing Behaviour in the Scottish Parliament', The Journal of Legislative Studies, 13(4), 48396.

Charles S. Bullock, I. and MacManus, S. A. (1981) 'Policy Responsiveness To the Black Electorate: Programmatic Versus Symbolic Representation', American Politics Quarterly, 9(3), 357-68.

Chiru, M. (2015) Rethinking constituency service: electoral institutions, candidate campaigns and personal vote in Hungary \& Romania. Central European University, Budapest.

Chiru, M. and Enyedi, Z. (2015) 'Choosing your own Boss: Variations of Representation Foci in Mixed Electoral Systems', The Journal of Legislative Studies, 21(4), 495-514.

Costello, R., Thomassen, J. and Rosema, M. (2012) 'European Parliament Elections and Political Representation: Policy Congruence between Voters and Parties', West European Politics, 35(6), 1226-48.

Curtice, J. and Shively, P. (2009) 'Who represents us best? One member or many?', HansDieter Klingemann (ed.) The Comparative Study of Electoral Systems. Oxford: Oxford University Press, pp. 171-92.

Dropp, K. and Peskowitz, Z. (2012) 'Electoral Security and the Provision of Constituency Service', The Journal of Politics, 74(1), 220-34.

Eulau, H. and Karps, P. D. (1977) 'The Puzzle of Representation: Specifying Components of Responsiveness', Legislative Studies Quarterly, 2(3), 233-54.

Heitshusen, V., Young, G. and Wood, D. M. (2005) 'Electoral Context and MP Constituency Focus in Australia, Canada, Ireland, New Zealand, and the United Kingdom', American Journal of Political Science, 49(1), 32-45. 
Hero, R. E. and Tolbert, C. J. (1995) 'Latinos and Substantive Representation in the U.S. House of Representatives: Direct, Indirect, or Nonexistent?', American Journal of Political Science, 39(3), 640-52.

Herron, E. S. (2002) 'Electoral Influences on Legislative Behavior in Mixed-Member Systems: Evidence from Ukraine’s Verkhovna Rada', Legislative Studies Quarterly, 27(3), 361-82.

Hutchings, V. L., McClerking, H. K. and Charles, G.-U. (2004) 'Congressional Representation of Black Interests: Recognizing the Importance of Stability', The Journal of Politics, 66(2), 450-68.

Ishiyama, J. (2000) 'Candidate Recruitment, Party Organisation and the Communist Successor Parties: The Cases of the MSzP, the KPRF and the LDDP', Europe-Asia Studies, 52(5), 875-96.

Judge, D. and Ilonszki, G. (1995) 'Member-Constituency Linkages in the Hungarian Parliament', Legislative Studies Quarterly, 20(2), 161-76.

Klingemann, H.-D. and Wessels, B. (2001) ‘The Political Consequence of Germany’s MixedMember System: Personalization at the Grass Roots?', in M. S. Shugart and M. P. Wattenberg (eds.), Mixed-Member Electoral Systems. The Best of Both Worlds?. Oxford: Oxford University Press, pp. 279-96.

Lancaster, T. D. (1986) 'Electoral Structures and Pork Barrel Politics', International Political Science Review, 7(1), 67-81.

Lancaster, T. D. and Patterson, W. D. (1990) 'Comparative Pork Barrel Politics: Perceptions from the West German Bundestag', Comparative Political Studies, 22(4), 458-77. Lundberg, T. C. (2006) 'Second-Class Representatives? Mixed-Member Proportional Representation in Britain', Parliamentary Affairs, 59(1), 60-77. 
Maestas, C. (2000) 'Professional Legislatures and Ambitious Politicians: Policy Responsiveness of State Institutions', Legislative Studies Quarterly, 25(4), 663-90.

Manow, P. (2013) 'Mixed Rules, Different Roles? An Analysis of the Typical Pathways into the Bundestag and of MPs' Parliamentary Behaviour', The Journal of Legislative Studies, 19(3), 287-308.

Mayhew, D. R. (1974) Congress: The Electoral Connection, Second Edition. Yale University Press.

Miller, W. E. and Stokes, D. E. (1963) 'Constituency Influence in Congress', The American Political Science Review, 57(1), 45-56.

Mitchell, P. (2000) 'Voters and their representatives: Electoral institutions and delegation in parliamentary democracies', European Journal of Political Research, 37(3), 335-51.

Montgomery, K. A. (1999) 'Electoral Effects on Party Behavior and Development', Party Politics, 5(4), 507-23.

Morlang, D. (1999) Socialists building capitalism: the Hungarian Socialist party and economic policy making. Duke University.

Norris, P. (1997) 'The puzzle of constituency service', The Journal of Legislative Studies, 3(2), 29-49.

Norton, P. and Wood, D. (1990) 'Constituency Service by Members of Parliament: Does It Contribute to a Personal Vote?', Parliamentary Affairs, 43(2), 196-208.

Olajos, I. and Szilágyi, Sz. (2015) 'The most important changes in the field of agricultural law in Hungary between 2011 and 2013', Journal of Agricultiral and Environmental Law, 5(15), 93.

Olivella, S. and Tavits, M. (2014) 'Legislative Effects of Electoral Mandates', British Journal of Political Science, 44(2), 301-321. 
Page, B. I. and Shapiro, R. Y. (1983) 'Effects of Public Opinion on Policy’, American Political Science Review, 77(1), 175-90.

Papp, Z. (2016) 'Shadowing the elected: mixed-member incentives to locally oriented parliamentary questioning', The Journal of Legislative Studies, 22(2), 216-36.

Pekkanen, R., Nyblade, B. and Krauss, E. S. (2006) 'Electoral Incentives in Mixed-Member Systems: Party, Posts, and Zombie Politicians in Japan', American Political Science Review, 100(02), 183-93.

Raisz, A. and Szilágyi, J. E. (2012) 'Development of agricultural law and related fields (environmental law, water law, social law, tax law) in the EU, in countries and in the WTO’, Journal of Agricultiral and Environmental Law, 7(12), 107-48.

Roberts, A. and Kim, B.-Y. (2011) 'Policy Responsiveness in Post-communist Europe: Public Preferences and Economic Reforms', British Journal of Political Science, 41(4), 819 39.

Russo, F. and Wiberg, M. (2010) 'Parliamentary Questioning in 17 European Parliaments: Some Steps towards Comparison', The Journal of Legislative Studies, 16(2), 215-32.

Sebők, M., Molnár, C. and Kubik, B. G. (2017) 'Exercising control and gathering information: the functions of interpellations in Hungary (1990-2014)', The Journal of Legislative Studies, 23(4), 465-83.

Shugart, M. S., Valdini, M. E. and Suominen, K. (2005) 'Looking for Locals: Voter Information Demands and Personal Vote-Earning Attributes of Legislators under Proportional Representation', American Journal of Political Science, 49(2), 437-49.

Stratmann, T. and Baur, M. (2002) 'Plurality Rule, Proportional Representation, and the German Bundestag: How Incentives to Pork-Barrel Differ across Electoral Systems', American Journal of Political Science, 46(3), 506-14. 
Szilágyi, J. E., Raisz, A. and Kocsis, B. E. (2017) 'New dimensions of the Hungarian agricultural law in respect of food sovereignty', Journal of Agricultiral and Environmental Law, 12(22), 160-201.

Thames, F. C. (2005) 'A House Divided Party Strength and the Mandate Divide in Hungary, Russia, and Ukraine', Comparative Political Studies, 38(3), 282-303.

Thomassen, J. and Andeweg, R. B. (2004) 'Beyond collective representation: individual members of parliament and interest representation in the Netherlands', The Journal of Legislative Studies, 10(4), 47-69.

Verba, S. and Nie, N. H. (1987) Participation in America: Political Democracy and Social Equality. Chicago: University of Chicago Press.

Wahlke, J. C., Eulau, H., Buchanan, W. and Ferguson, L. C. (1962) The Legislative System. Explorations in Legislative Behavior. New York: Wiley.

Wiberg, M. and Koura, A. (1994) 'The Logic of Parliamentary Questions', Matti Wiberg (ed.) Parliamentary Control in Nordic Countries. Helsinki: Finnish Political Science Association, pp. 19-43. 